\title{
Performance of NGA Models in Predicting Ground Motion Parameters of The Strong Earthquake
}

\author{
Lindung Zalbuin Mase \\ ${ }^{1}$ Department of Civil Engineering, University of Bengkulu, Bengkulu, INDONESIA \\ "Corresponding authors: Imase@unib.ac.id \\ SUBMITTED 6 July 2019 REVISED 29 July 2019 ACCEPTED 13 August 2019
}

\begin{abstract}
Next Generation Attenuation (NGA) West 1 and 2 models are employed to predict the ground motion parameters of strong earthquake during the 6.9 Mw Kobe Earthquake in 1995. This study is initiated by collecting the data of ground motion parameters of the earthquake. Furthermore, the ground motion prediction is performed by using the NGA models. There are three ground motion parameters observed, i.e. peak ground acceleration (PGA), spectral acceleration (SA) at 0.2 second and SA at 1 second. The performances of the models are evaluated by using the Residual Values and Root Mean Square (RMS) Error. The results show that the NGA models could predict the ground motion parameters quite appropriately. It can be seen from the correlation values of the observed and the predicted values, which is relatively consistent each other, especially for peak ground acceleration. In general, this study could recommend the procedure in selecting the attenuation model for strong earthquakes. The study framework could be implemented to predict the ground motion in other regions.
\end{abstract}

KEYWORDS Attenuation; Ground Motion; Earthquake; Statistical Parameters; Peak Ground Acceleration; Spectral Acceleration

(0) The Author(s) 2019. This article is distributed under a Creative Commons Attribution-ShareAlike 4.0 International license.

\section{INTRODUCTION}

An earthquake is a unique phenomenon resulted by the activity of tectonic region on the earth crustal. An earthquake occurred in a region could be felt by the region itself and other surrounding areas. The impact on each area could be varied. It is indicated that an earthquake has uncertainty in terms of its mechanisms and impacts, respectively (Rhoades and Dowrick, 2000). Abrahamson and Bommer (2005) suggested that the scientific uncertainty in the earthquake occurrence and ground motion or epistemic uncertainty should be considered in seismic hazard analysis. Atkinson (2006) mentioned that the ground motions amplitude is produced from the earthquake magnitude and distance plays an important role in seismic hazard mitigation. Therefore, the earthquake characteristic and probable impact should be initially understood in seismic hazard analysis (Kramer, 1996).

Studies focused on the seismic hazard assessment related to the ground shaking are strongly associated with the ground motion prediction using the attenuation models (Shoja-Taheri et al.,
2010). Nowadays, the attenuation models have been intensively developed. Next Generation Attenuation (NGA) West models is one of the attenuation models project, which was developed by Pacific Earthquake Engineering Research (PEER) Institute.

Several researchers such as Abrahamson and Silva (2008), Boore and Atkinson (2008), Campbell and Bozorgnia (2008 and 2014), Chiou and Youngs (2008 and 2014), Idriss' (2008 and 2014), Abrahamson et al. (2014), Boore et al. (2014) has involved in the project and released the attenuation relationships. Specifically, NGA West is aimed to predict the ground motion due to the seismic fault activity in the western region of USA. Those attenuation models have been implemented in the other regions in the world, such as performed by Mase et al. (2018a, 2018b, and 2018c) to estimate the ground motion of the moderate earthquake occurred in ThailandMyanmar Region. Regarding this, there is a necessity to observe the performance of NGA models in predicting the ground motion during the strong earthquake. 
In January 1995, a strong earthquake with magnitude of $6.9 \mathrm{Mw}$ destructed the Kansai Region in Japan. This earthquake is later known as the Kobe Earthquake. The $6.9 \mathrm{Mw}$ Kobe Earthquake was triggered by the activity of Awaji Fault, which is categorized as the slip-strike fault. Katayama (2004) and Wakamatsu and Numata (2014) reported that the earthquake not only killed thousands of people, but also destroyed the infrastructures and triggered liquefaction along coastal area of Osaka Bay, as well as the huge fire in Kobe. Tamura (2014) stated that the Kobe Earthquake is one of most devastating earthquakes in Japanese earthquake history. During the earthquakes, several seismic stations in Kansai Region recorded the earthquake ground motions, as compiled by Centre of Earthquake Strong Motion Database or CESMD (2018). This study presented the performance of NGA West 1 models and NGA West 2 models in predicting the ground motion of the Kobe Earthquake.

The ground motion parameters including peak ground acceleration (PGA), spectral acceleration (SA) at $0.2 \mathrm{sec}$, and SA at $1 \mathrm{sec}$ were analysed. The comparison of ground motion predictions and the recorded values were presented in statistical approach. In general, this study could Those seismic stations were located within 200 $\mathrm{km}$ in radius of the Kobe Earthquake Epicentre. The ground motion parameters including PGA, SA at $0.2 \mathrm{sec}$, and SA at $1 \mathrm{sec}$ that were recorded during the Kobe Earthquake are compiled in Table 1. As presented in Table 1, it can be seen that the maximum PGA or PGAmax that appeared during the earthquake was about $0.821 \mathrm{~g}$ (recorded at KJMA Station). This station is the closest station recommend the procedure in selecting the suitable attenuation model for strong earthquakes. The study framework could be implemented to predict the ground motion in other regions.

\section{STUDY AREA}

The Kansai Region is an area surrounded by many active faults, as presented in Figure 1. Those faults could frequently trigger earthquakes in the region with various magnitudes. The $6.9 \mathrm{Mw}$ Kobe Earthquake, which occurred on 17 January 1995 was an earthquake triggered by one of those active faults. Soga (1998) mentioned that Awaji Fault (Figure 1) is suspected as the active fault that triggered the Kobe Earthquake in 1995. The earthquake epicentre was relatively close to the capital cities in Kansai Region, such as Osaka, Kobe, and Kyoto. CESMD (2018) also reported that the earthquake focal depth was only $17 \mathrm{~km}$. Therefore, the most destructive damage was massively found along the coastal area, where the socio-economic activities were centralised. During the earthquake, several seismic stations in Western and Eastern Japan recorded the ground motion. The locations of seismic stations are presented in Figure 1 (in red-yellow triangle).

to the Kobe earthquake rupture that has the distance to the surface projection ( $\mathrm{Rjb}$ ) of about $1.8 \mathrm{~km}$ and the rupture distance (Rrup) of about $2.4 \mathrm{~km}$. According to National Earthquake Hazard Reduction Provision or NEHRP (1998), the site class of KJMA station is Site Class C. From Table 1 , it is shown that the stations' site classes are generally dominated by Site Class C and D. 
3

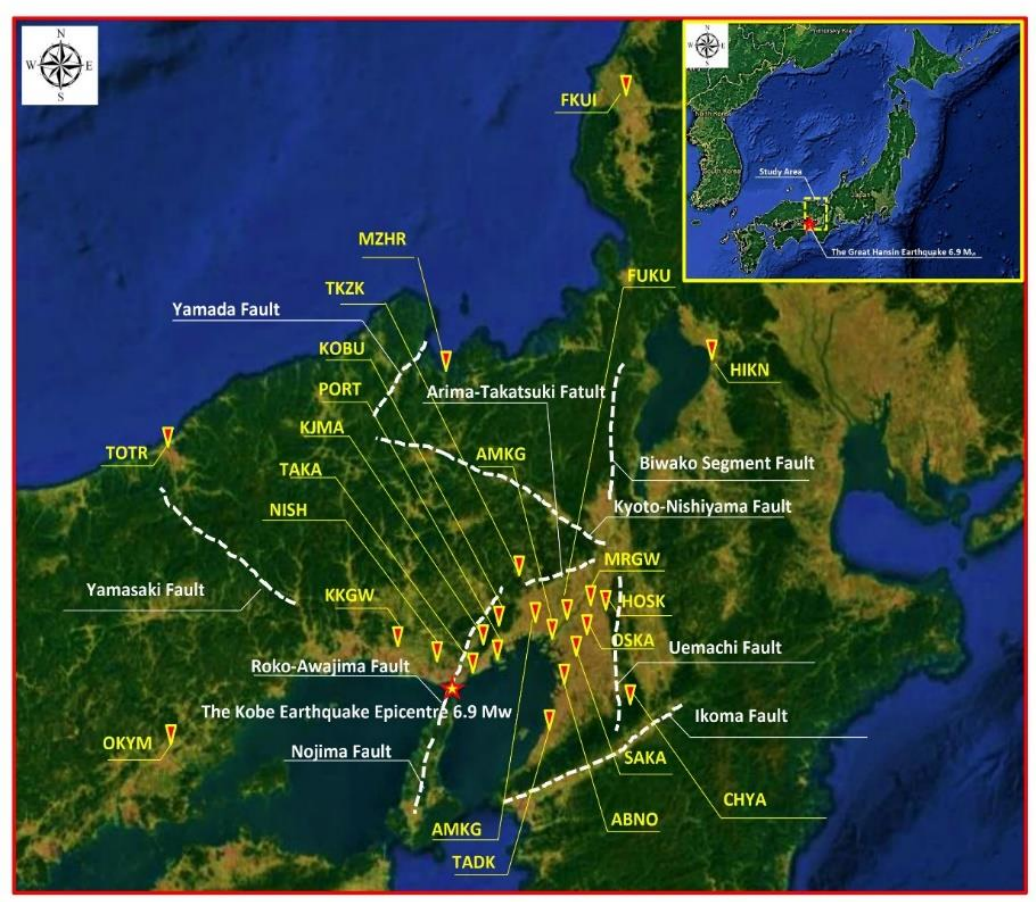

Figure 1. Location of seismic stations, earthquake epicentre, and active faults (modified from Google Earth (2018))

\section{THEORY AND METHODS}

\subsection{NGA Models}

In 2008, earthquake engineering researchers that were incorporated in PEER released the new attenuation model, which was called NGA West 1 . The NGA West 1 was a project of ground motion prediction for the earthquake triggered by the active tectonic region in western part of USA. There were five NGA West 1 models released, which are Abrahamson and Silva's (2008) model, Boore and Atkinson's (2008) model, Campbell and Bozorgnia's (2008) model, Chiou and Youngs' (2008) model, and Idriss' (2008) model. In those attenuation models, only Idriss' (2008) model that was specifically addressed to estimate the ground motion at rock sites, or in another word, Idriss' model is only suitable for Site Class B and $A$ in NEHRP. The implementation of NGA West 1 models has been reported by several researchers such as Mase et al. (2018a and 2018b), Ornthammarath (2013), as well as
Ornthammarath and Warnitchai (2016) that used it for seismic hazard analysis of the active tectonic region in Northern Thailand.

In 2014, the updated models of NGA West 1 models were released. The project was later known as NGA West 2. Shahi and Baker (2014) suggested that the goal of the NGA West 2 was to provide the refined models for estimating the ground motion parameters. Similar to previous NGA West 1, NGA West 2 project also involved several researchers, such as Abrahamson et al. (2014), Boore et al. (2014), Campbell and Bozorgnia (2014), Chiou and Youngs (2014), and Idriss' (2014). The models have been performed to estimate the ground motion of the earthquake triggered by the active tectonic region such as performed by Kusumahadi et al. (2018) and Mase et al. (2018c) to estimate ground motion during the Mae Lao Earthquake in 2014. 
Table 1. Summary of ground motion record during the Kobe Earthquake (CESMD, 2018)

\begin{tabular}{|c|c|c|c|c|c|c|c|c|c|c|c|}
\hline \multirow[t]{2}{*}{ No } & \multirow{2}{*}{$\begin{array}{l}\text { Stations } \\
\text { Code }\end{array}$} & \multirow[t]{2}{*}{ Locations } & \multirow[t]{2}{*}{ Code } & \multirow{2}{*}{$\begin{array}{l}\text { Lat } \\
\left({ }^{\circ}\right)\end{array}$} & \multirow{2}{*}{$\begin{array}{l}\text { Long } \\
\left({ }^{\circ}\right)\end{array}$} & \multirow{2}{*}{$\begin{array}{l}\mathrm{R}_{\mathrm{jb}} \\
(\mathrm{km}) \\
\end{array}$} & \multirow{2}{*}{$\begin{array}{l}\text { R } \\
\text { rup } \\
(\mathrm{km})\end{array}$} & \multirow{2}{*}{$\begin{array}{l}\text { Site } \\
\text { Class } \\
\text { (NEHRP) }\end{array}$} & \multirow{2}{*}{$\begin{array}{l}\text { PGA } \\
(g) \\
\end{array}$} & \multirow{2}{*}{$\begin{array}{l}\text { SA } \\
(0.2 \mathrm{sec}) \\
(\mathrm{g})\end{array}$} & \multirow{2}{*}{$\begin{array}{l}\text { SA } \\
(1 \mathrm{sec}) \\
(\mathrm{g})\end{array}$} \\
\hline & & & & & & & & & & & \\
\hline 1 & TKZK & $\begin{array}{l}\text { Takarazuka } \\
\text { Kobe }\end{array}$ & TKZK & 34.81 & 135.34 & 0.2 & 0.7 & $\mathrm{C}$ & 0.693 & 1.745 & 0.827 \\
\hline 2 & KOBU & University & KOBU & 34.73 & 135.24 & 1.2 & 1.7 & $\mathrm{C}$ & 0.380 & 0.606 & 0.258 \\
\hline 3 & KJMA & KJMA & KJMA & 34.68 & 135.18 & 1.8 & 2.4 & $\mathrm{C}$ & 0.821 & 0.893 & 1.450 \\
\hline 4 & TAKA & Takatori & TAKA & 34.65 & 135.14 & 2.4 & 3.3 & $\mathrm{C}$ & 0.615 & 2.095 & 1.420 \\
\hline 5 & PORT & Port Island & PORT & 34.67 & 135.20 & 4.2 & 4.8 & $\mathrm{C}$ & 0.562 & 1.195 & 0.334 \\
\hline 6 & NISH & Nishi Akashi & NISH & 34.66 & 134.96 & 9.3 & 10.2 & C & 0.509 & 1.476 & 0.307 \\
\hline 7 & AMGK & Amagasaki & AMGK & 34.72 & 135.41 & 10.4 & 10.7 & $\mathrm{D}$ & 0.363 & 0.429 & 0.592 \\
\hline 8 & FUKU & Fukusima & FUKU & 34.69 & 135.47 & 160.2 & 161.9 & D & 0.042 & 0.058 & 0.102 \\
\hline 9 & OSKA & Osaka & OSKA & 34.69 & 135.50 & 17.6 & 18.5 & D & 0.243 & 0.374 & 0.331 \\
\hline 10 & OSAK & Osaka & OSAK & 34.68 & 135.52 & 20.5 & 20.6 & D & 0.079 & 0.128 & 0.241 \\
\hline 11 & MRGW & Morigawachi & MRGW & 34.68 & 135.57 & 23.5 & 24.1 & D & 0.214 & 0.291 & 0.640 \\
\hline 12 & ABNO & Abeno & ABNO & 34.64 & 135.52 & 23.5 & 24.1 & D & 0.234 & 0.311 & 0.176 \\
\hline 13 & KKGW & Kakogawa & KKGW & 34.76 & 134.84 & 25.3 & 26.3 & D & 0.345 & 0.937 & 0.349 \\
\hline 14 & HOSK & Higashioska & HOSK & 34.68 & 135.61 & 26.8 & 27.2 & $\mathrm{D}$ & 0.158 & 0.166 & 0.577 \\
\hline 15 & SAKA & Sakai & SAKA & 34.56 & 135.47 & 26.9 & 27.6 & D & 0.157 & 0.392 & 0.192 \\
\hline 16 & TADK & Tadoka & TADK & 34.48 & 135.41 & 33.4 & 32.5 & $\mathrm{D}$ & 0.294 & 1.053 & 0.236 \\
\hline 17 & CHYA & Chihaya & CHYA & 34.44 & 135.66 & 48.6 & 49.3 & D & 0.108 & 0.274 & 0.034 \\
\hline 18 & MZHR & Maizhuru & MZHR & 35.45 & 135.32 & 74.2 & 72.2 & $\mathrm{C}$ & 0.070 & 0.120 & 0.014 \\
\hline 19 & HIKN & Hikone & HIKN & 35.27 & 136.25 & 96.2 & 97.6 & $\mathrm{D}$ & 0.148 & 0.178 & 0.160 \\
\hline 20 & OKYM & Okayama & OKYM & 34.66 & 133.92 & 96.3 & 96.9 & $\mathrm{C}$ & 0.081 & 0.205 & 0.011 \\
\hline 21 & TOTR & Tottori & TOTR & 35.49 & 134.24 & 121.1 & 120.0 & D & 0.076 & 0.094 & 0.211 \\
\hline 22 & FKUI & Fukui & FKUI & 36.05 & 136.23 & 160.2 & 161.9 & D & 0.042 & 0.058 & 0.102 \\
\hline
\end{tabular}

In general, the NGA models were developed to cover uncertainty in earthquake. Several parameters such as site class, the magnitude, the distance, and the fault effect are considered in NGA models. Therefore, the models are relatively complex, which are needed to be carefully considered in the analysis. Table 2 summaries the applicability of NGA models for analysis of ground motion. In Table 2, it can be seen that all models are considered the maximum Rrup of about $300 \mathrm{~km}$ and the maximum Rjb of about 400 $\mathrm{km}$. It indicates that the application of NGA models is not reliable to estimate ground motion prediction for the remote earthquakes. To obtain reliable results, the minimum Rrup values should be equal to Rjb. All NGA models are also recommended to be used for the earthquakes with the magnitude up to $8.5 \mathrm{Mw}$. In addition, the magnitude of fault earthquake type was also considered in the models, especially for model from Boore and Atkinson, and from Boore et al., Campbell and Bozorgnia's models, as well as the Chiou and Young's models. As previously mentioned, the NGA models are capable of predicting the earthquake on rock and soil sites, with the time-averaged shear wave velocity for first $30 \mathrm{~m}$ depth (Vs30) were ranging from $150 \mathrm{~m} / \mathrm{s}$ to $1000 \mathrm{~m} / \mathrm{s}$. Idriss' models are only aimed for predicting the earthquake ground motion on rock sites, with the minimum Vs30 of about $450 \mathrm{~m} / \mathrm{s}$. Therefore, for this study, Idriss' models were not included in the analysis of the Kobe Earthquake ground motion. Additionally, the application of the models could be performed since the maximum Rjb and Rrup values were still in the recommended ranges by the models. 
Table 2. Summary of NGA models' applicability

\begin{tabular}{|c|c|c|c|c|}
\hline NGA models & Symbols & Parameters & Unit & Model Ranges \\
\hline \multirow{3}{*}{$\begin{array}{l}\text { Abrahamson-Silva } \\
\text { (2008) and } \\
\text { Abrahamson et al. } \\
\text { (2014) }\end{array}$} & $\mathrm{M}_{\mathrm{w}}$ & Moment magnitude & $\mathrm{M}_{\mathrm{w}}$ & $3 \leq \mathrm{M}_{\mathrm{w}} \leq 8.5$ \\
\hline & $\mathrm{R}_{\text {rup }}$ & Distance to Rupture & $\mathrm{km}$ & $0 \leq \mathrm{R}_{\text {rup }} \leq 300$ \\
\hline & $\mathrm{V}_{\mathrm{s30}}$ & $\begin{array}{l}\text { The time-averaged of shear wave velocity } \\
\text { for first } 30 \mathrm{~m} \text { depth }\end{array}$ & $\mathrm{m} / \mathrm{s}$ & $180 \leq \mathrm{V}_{\mathrm{S} 30} \leq 1000$ \\
\hline \multirow{6}{*}{$\begin{array}{l}\text { Boore-Atkinson (2008) } \\
\text { and Boore et al. (2014) }\end{array}$} & $\mathrm{M}_{\mathrm{w}}(\mathrm{SS})$ & $\begin{array}{l}\text { Moment magnitude for slip strike } \\
\text { earthquake }\end{array}$ & $\mathrm{M}_{\mathrm{w}}$ & $3 \leq \mathrm{M}_{\mathrm{w}} \leq 8.5$ \\
\hline & $\mathrm{M}_{\mathrm{w}}(\mathrm{RS})$ & $\begin{array}{l}\text { Moment magnitude for reverse strike } \\
\text { earthquake }\end{array}$ & $\mathrm{M}_{\mathrm{w}}$ & $3 \leq \mathrm{M}_{\mathrm{w}} \leq 8.5$ \\
\hline & $\mathrm{M}_{\mathrm{w}}(\mathrm{NM})$ & $\begin{array}{l}\text { Moment magnitude for normal fault } \\
\text { earthquake }\end{array}$ & $\mathrm{M}_{\mathrm{w}}$ & $3 \leq \mathrm{M}_{\mathrm{w}} \leq 7.0$ \\
\hline & $\mathrm{R}_{\mathrm{jb}}$ & Distance to surface projection & $\mathrm{km}$ & $0 \leq \mathrm{R}_{\mathrm{jb}} \leq 400$ \\
\hline & $\mathrm{V}_{\mathrm{s} 30}$ & $\begin{array}{l}\text { The time-averaged of shear wave velocity } \\
\text { for first } 30 \mathrm{~m} \text { depth }\end{array}$ & $\mathrm{m} / \mathrm{s}$ & $150 \leq \mathrm{V}_{\mathrm{S} 30} \leq 1500$ \\
\hline & $\mathrm{Z}_{1.0}$ & Depth to $V_{S}$ of $1 \mathrm{~km} / \mathrm{sec}$ & $\mathrm{km}$ & $0 \leq \mathrm{Z}_{1.0} \leq 3$ \\
\hline \multirow{9}{*}{$\begin{array}{l}\text { Campbell-Bozorgnia } \\
\text { (2008) and Campbell- } \\
\text { Bozorgnia (2014) }\end{array}$} & $\mathrm{M}_{\mathrm{w}}(\mathrm{SS})$ & $\begin{array}{l}\text { Moment magnitude for slip strike } \\
\text { earthquake }\end{array}$ & $\mathrm{M}_{\mathrm{w}}$ & $3 \leq \mathrm{M}_{\mathrm{w}} \leq 8.5$ \\
\hline & $\mathrm{M}_{\mathrm{w}}(\mathrm{RS})$ & $\begin{array}{l}\text { Moment magnitude for reverse strike } \\
\text { earthquake }\end{array}$ & $\mathrm{M}_{\mathrm{w}}$ & $3 \leq \mathrm{M}_{\mathrm{w}} \leq 8.5$ \\
\hline & $\mathrm{M}_{\mathrm{w}}(\mathrm{NM})$ & $\begin{array}{l}\text { Moment magnitude for normal fault } \\
\text { earthquake }\end{array}$ & $\mathrm{M}_{\mathrm{w}}$ & $3 \leq \mathrm{M}_{\mathrm{w}} \leq 7.5$ \\
\hline & $\mathrm{R}_{\mathrm{rup}}$ & Distance to Rupture & $\mathrm{km}$ & $0 \leq \mathrm{R}_{\mathrm{rup}} \leq 300$ \\
\hline & $\mathrm{V}_{\mathrm{S} 30}$ & $\begin{array}{l}\text { The time-averaged of shear wave velocity } \\
\text { for first } 30 \mathrm{~m} \text { depth }\end{array}$ & $\mathrm{m} / \mathrm{s}$ & $150 \leq \mathrm{V}_{\mathrm{S} 30} \leq 1500$ \\
\hline & $\mathrm{Z}_{2.5}$ & Depth to $\mathrm{V}_{\mathrm{s}}$ of $2.5 \mathrm{~km} / \mathrm{sec}$ & $\mathrm{km}$ & $0 \leq \mathrm{Z}_{2.5} \leq 2.5$ \\
\hline & $Z_{\text {hyp }}$ & Hypocentre depth from the earthquake & $\mathrm{km}$ & $0 \leq \mathrm{Z}_{\mathrm{hyp}} \leq 20$ \\
\hline & $Z_{\text {tor }}$ & Depth to top of coseismal rupture & $\mathrm{km}$ & $0 \leq \mathrm{Z}_{\mathrm{tor}} \leq 20$ \\
\hline & dip & Average dip of the rupture plane & degree & $15 \leq \operatorname{dip} \leq 90$ \\
\hline \multirow{7}{*}{$\begin{array}{l}\text { Chiou-Youngs (2008) } \\
\text { and Chiou-Youngs } \\
\text { (2014) }\end{array}$} & $\mathrm{M}_{\mathrm{w}}(\mathrm{SS})$ & $\begin{array}{l}\text { Moment magnitude for slip strike } \\
\text { earthquake }\end{array}$ & $\mathrm{M}_{\mathrm{w}}$ & $3 \leq \mathrm{M}_{\mathrm{w}} \leq 8.0$ \\
\hline & $\mathrm{M}_{\mathrm{w}}(\mathrm{RS})$ & $\begin{array}{l}\text { Moment magnitude for reverse strike } \\
\text { earthquake }\end{array}$ & $\mathrm{M}_{\mathrm{w}}$ & $3 \leq \mathrm{M}_{\mathrm{w}} \leq 8.5$ \\
\hline & $\mathrm{M}_{\mathrm{w}}(\mathrm{NM})$ & $\begin{array}{l}\text { Moment magnitude for normal fault } \\
\text { earthquake }\end{array}$ & $\mathrm{M}_{\mathrm{w}}$ & $3 \leq \mathrm{M}_{\mathrm{w}} \leq 8.0$ \\
\hline & $\mathrm{R}_{\text {rup }}$ & Distance to Rupture & $\mathrm{km}$ & $0 \leq \mathrm{R}_{\text {rup }} \leq 300$ \\
\hline & $\mathrm{V}_{\mathrm{S} 30}$ & $\begin{array}{l}\text { The time-averaged of shear wave velocity } \\
\text { for first } 30 \mathrm{~m} \text { depth }\end{array}$ & $\mathrm{m} / \mathrm{s}$ & $180 \leq V_{S 30} \leq 1500$ \\
\hline & $\mathrm{Z}_{1.0}$ & Depth to $V_{s}$ of $1 \mathrm{~km} / \mathrm{sec}$ & $\mathrm{km}$ & $\mathrm{Z}_{1.0} \leq 20$ \\
\hline & $\mathrm{Z}_{\text {tor }}$ & Depth to top of coseismal rupture & $\mathrm{km}$ & $0 \leq \mathrm{Z}_{\mathrm{tor}} \leq 10$ \\
\hline \multirow{3}{*}{$\begin{array}{l}\text { Idriss (2008) and Idriss } \\
\text { (2014) }\end{array}$} & $\mathrm{M}_{\mathrm{w}}$ & $\begin{array}{l}\text { Moment magnitude for slip strike } \\
\text { earthquake }\end{array}$ & $\mathrm{M}_{\mathrm{w}}$ & $5 \leq \mathrm{M}_{\mathrm{w}} \leq 7.0$ \\
\hline & $\mathrm{R}_{\mathrm{rup}}$ & Distance to Rupture & $\mathrm{km}$ & $\mathrm{R}_{\text {rupt }} \leq 150$ \\
\hline & $\mathrm{V}_{\mathrm{s30}}$ & $\begin{array}{l}\text { The time-averaged of shear wave velocity } \\
\text { for first } 30 \mathrm{~m} \text { depth }\end{array}$ & $\mathrm{m} / \mathrm{s}$ & $\mathrm{V}_{\mathrm{S} 30} \geq 450$ \\
\hline
\end{tabular}




\subsection{Methodology}

The study framework of this research is illustrated in Figure 2. This study was initiated by collecting the information of the Kobe Earthquake occurred in January 1995, especially related to local site condition and tectonic setting in the Kansai Region. Furthermore, the ground motion data during the Kobe Earthquake were collected from CESMD (2018). The sorting analysis based on epicentre distance was performed to find the list of recorded ground motion from the closest station to the furthest one. This analysis would also help in determining $\mathrm{Rjb}$ and Rrup. Afterwards, the ground motion prediction (GMP) analysis was performed by using the NGA West 1 and NGA West2 Models. There were three ground motion parameters analysed in this study, which are PGA, SA at $0.2 \mathrm{sec}$, and SA at $1 \mathrm{sec}$. PGA represents the maximum surface acceleration during the earthquake, and it should be noted that only Idriss' models that were not employed in the analysis, since the site class of the stations were dominated by Site Class C and D with Vs30 of about 300 to $450 \mathrm{~m} / \mathrm{s}$. To observe the performance of NGA models in predicting the ground motion of Kobe Earthquake, the ground motion prediction and the recorded ground motion were compared corresponding to the epicentre distance, such as Rjb. In addition, the confidential interval with the deviation standard was also applied in the analysis. In this study, the residual analysis for PGA, SA at $0.2 \mathrm{sec}$, and SA at 1 sec was also performed to observe the overestimation and underestimation models to the model. The formulations of residual values for PGA and SA were expressed in the following,

$$
\begin{aligned}
& R_{i(P G A)}=\ln \left(P G A_{i}\right)_{\text {rec }}-\ln \left(P G A_{i}\right)_{c a l} \\
& R_{i(S A)}=\ln \left(S A_{i}\right)_{\text {rec }}-\ln \left(S A_{i}\right)_{\text {cal }}
\end{aligned}
$$

in which $R_{i(P G A)}$ and $R_{i(S A)}$ are the residual values of the i ground motion for PGA and SA, respectively, and are the observed PGA and median value of predicted PGA, respectively. The negative residual values mean the recorded value is overestimated by the predicted value resulted from the models and vice versa.
The Root Mean Square (RMS) Error analysis was also performed. This parameter was used to measure the differences between the recorded ground motion and the predicted ground motion. The formulation of RMS Error for PGA and SA are expressed in Equations 3 and 4. From the RMS Error, a smaller RMS Error means a smaller gap between the predicted and the observed values. The smallest RMS Error could describe the best models in predicting ground motion parameters.

$$
\begin{aligned}
& R M S \text { Error }=\sqrt{\frac{\sum_{i=1}^{n}\left(P G A_{o b s}-P G A_{c a l}\right)^{2}}{n}} \\
& R M S \text { Error }=\sqrt{\frac{\sum_{i=1}^{n}\left(S A_{o b s}-S A_{c a l}\right)^{2}}{n}}
\end{aligned}
$$

in which $\mathrm{n}$ is the total observed data, $P G A_{o b s}$ and $S A_{o b s}$ are the observed PGA and the observed SA, respectively, and are the predicted PGA and the predicted SA, respectively.

\section{RESULTS AND DISCUSSION}

The example of comparison on observed ground motion and predicted ground motion corresponding to $\mathrm{Rjb}$ are presented in Figures 3 and 4. Figure 3 presents the performance of Abrahamson-Silva's (2008) model and Abrahamson et al. (2014) model, whereas Figure 4 shows the performance of Campbell and Bozorngia's (2008) models and Campbell and Bozorgnia's (2014) model.

In Figure 3, the prediction from both Abrahamson-Silva's (2008) model and Abrahamson et al.'s (2014) model is relatively accurate in predicting the ground motion within radius of $200 \mathrm{~km}$, especially for PGA. For both SA at $0.2 \mathrm{sec}$ and $\mathrm{SA}$ at $1 \mathrm{sec}$, the prediction is not as accurate as PGA. This could be caused by the varied conditions of the local site where the seismic station was installed. The local site condition was correlated with Vs30. A larger Vs30 means a better layer resistance or geological condition. For the study area (Table 1), Site Class C represents site that have Vs30 in range of 180 $\mathrm{m} / \mathrm{s}$ to $360 \mathrm{~m} / \mathrm{s}$, whereas Site Class D was for site with Vs30 in range of $360 \mathrm{~m} / \mathrm{s}$ to $760 \mathrm{~m} / \mathrm{s}$. In 
NGAmodels, characteristic of local site is commonly known as the main parameters in determining the ground motion of the sites. Therefore, the varied conditions of the local site could play important role in NGA models analysis. In general, the prediction of resulted from both models was still in the deviation ranges, i.e. \pm one standard deviation (Figure 3). It indicates that the uncertainty solution provided by the model is still acceptable. In general, Abrahamson et al. (2014) tend to predict more accurately than the previous model i.e. Abrahamson et al. (2014). It exhibits that the prediction is relatively close to the observation. In addition, the range of deviation provided by Abrahamson et al. (2014) model tends to be smoother.

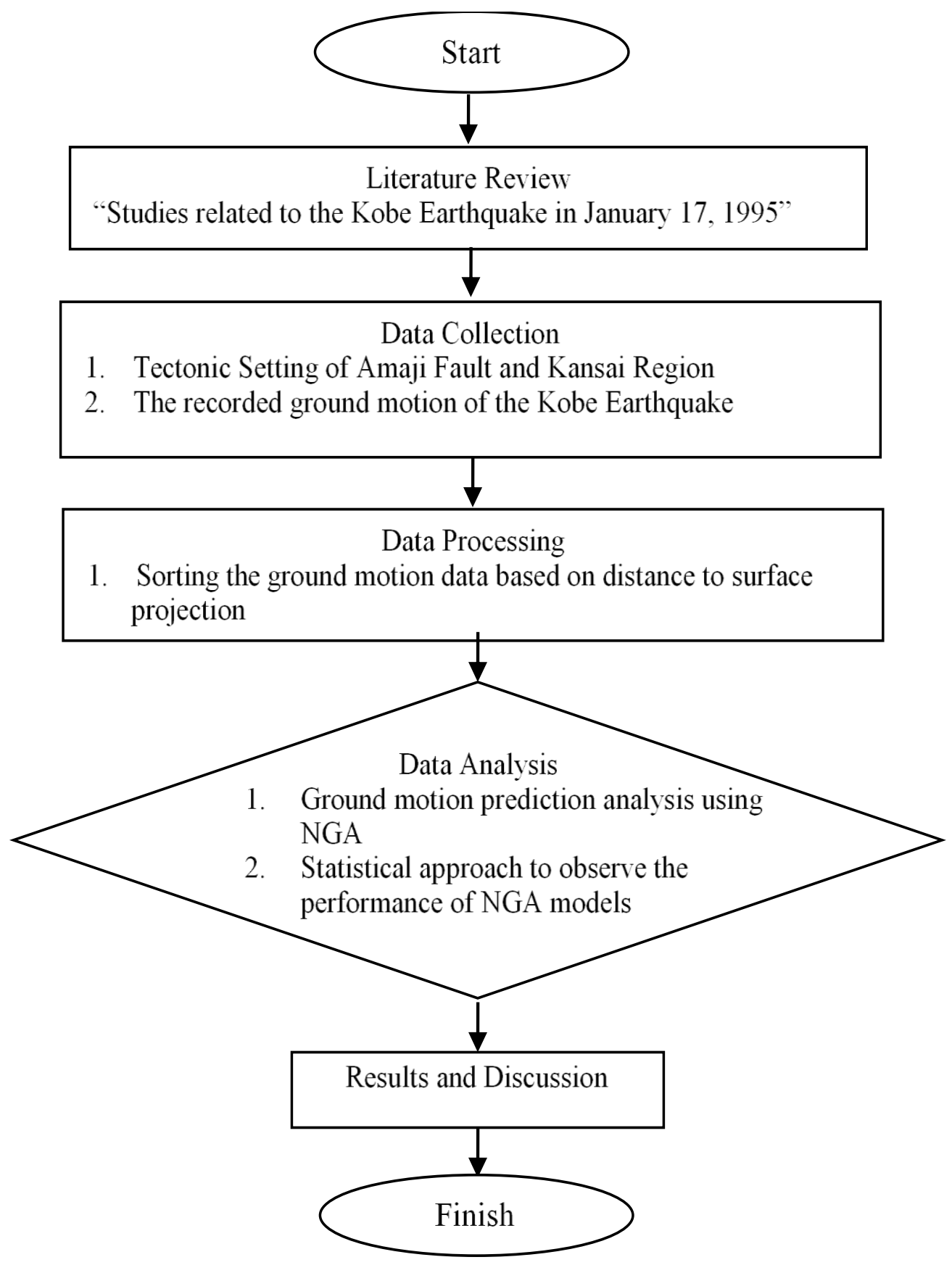

Figure 2. Flowchart of this study 
The Figure 4 shows the prediction from model from Campbell and Bozorgnia (2008) and model from Campbell and Bozorgnia (2014). Generally, Campbell and Bozorgnia's model could exhibit the best prediction of ground motion during the Kobe Earthquake for sites with radius less than $200 \mathrm{~km}$. The results were generally consistent with the NGA models applicability (Table 2), i.e. more reliable to predict ground motion of site which has the maximum radius of about $400 \mathrm{~km}$. Several studies, such as performed by Mase et al. (2018a and 2018b) and Likitlersuang et al. (2019) mentioned that NGA models tend to be more accurate in predicting the ground motion at a distance less than $400 \mathrm{~km}$. As presented in Figure 4, NGA models analysis was consistent with previous studies where NGA models tend to be reliable to estimate the ground motion of the site which has the distance less than $400 \mathrm{~km}$, especially for PGA (Mase et al., 2018a). For SA at $0.2 \mathrm{sec}$ and SA at $1 \mathrm{sec}$, the prediction was not as well as PGA. Similar to Abrahamson-Silva (2008) and Abrahamson et al. (2014) models, the uncertainty of geological condition on each seismic station could affect the prediction.

Figure 5 presents the residual analysis results estimated by Equation 1 and 3, for PGA, SA at 0.2 sec, and $1 \mathrm{sec}$. It can be seen that both NGA West 1 and NGA West 2 show both overestimation and underestimation. Generally, the NGA West 2 has improved the prediction. It can be seen from the reduction of residual values by NGA West 2 models, especially for PGA. For SA at $0.2 \mathrm{sec}$ and SA at $1 \mathrm{sec}$, both NGA West 1 and NGA West 2 models have not significantly improved the prediction. It can be seen from the interpretation that in majority, residual values were not too different. Similar result was also found by Mase et al. (2018a, 2018b) and Ornthammarath (2013) for the Tarlay Earthquake of Northern Thailand in 2013.

Figures 6 and 7 present the relative observation of the recorded ground motion and the predicted ground motion for NGA West 1 and NGA West 2 , respectively. In Figure 6, For PGA Campbell and Bozorgnia (2008) and Boore and Atkinson (2008) models slightly underestimated the recorded ground motion, whereas Abrahamson and Silva (2008) and Chiou and Youngs (2008) relatively overestimated the recorded ground motion for PGA. For SA at $0.2 \mathrm{sec}$, Abrahamson and Silva (2008), Boore and Atkinson (2008), Chiou and Youngs (2008) generally overestimated the recorded ground motion, whereas Campbell and Bozorgnia (2008) showed the opposite. For NGA West 2, a similar tendency was also observed. Abrahamson et al. (2014), Chiou and Youngs (2014) showed the overestimation of PGA values. On the contrary, Campbell and Bozorgnia (2014) and Boore et al. (2014) were generally underestimated PGA. All models generally slightly overestimated SA at $0.2 \mathrm{sec}$. For SA at 1 sec, Abrahamson et al. (2014) and Chiou and Youngs showed an overestimation, whereas Boore et al. (2014) and Campbell and Bozorgnia (2014) showed underestimation of the recorded ground motion. 

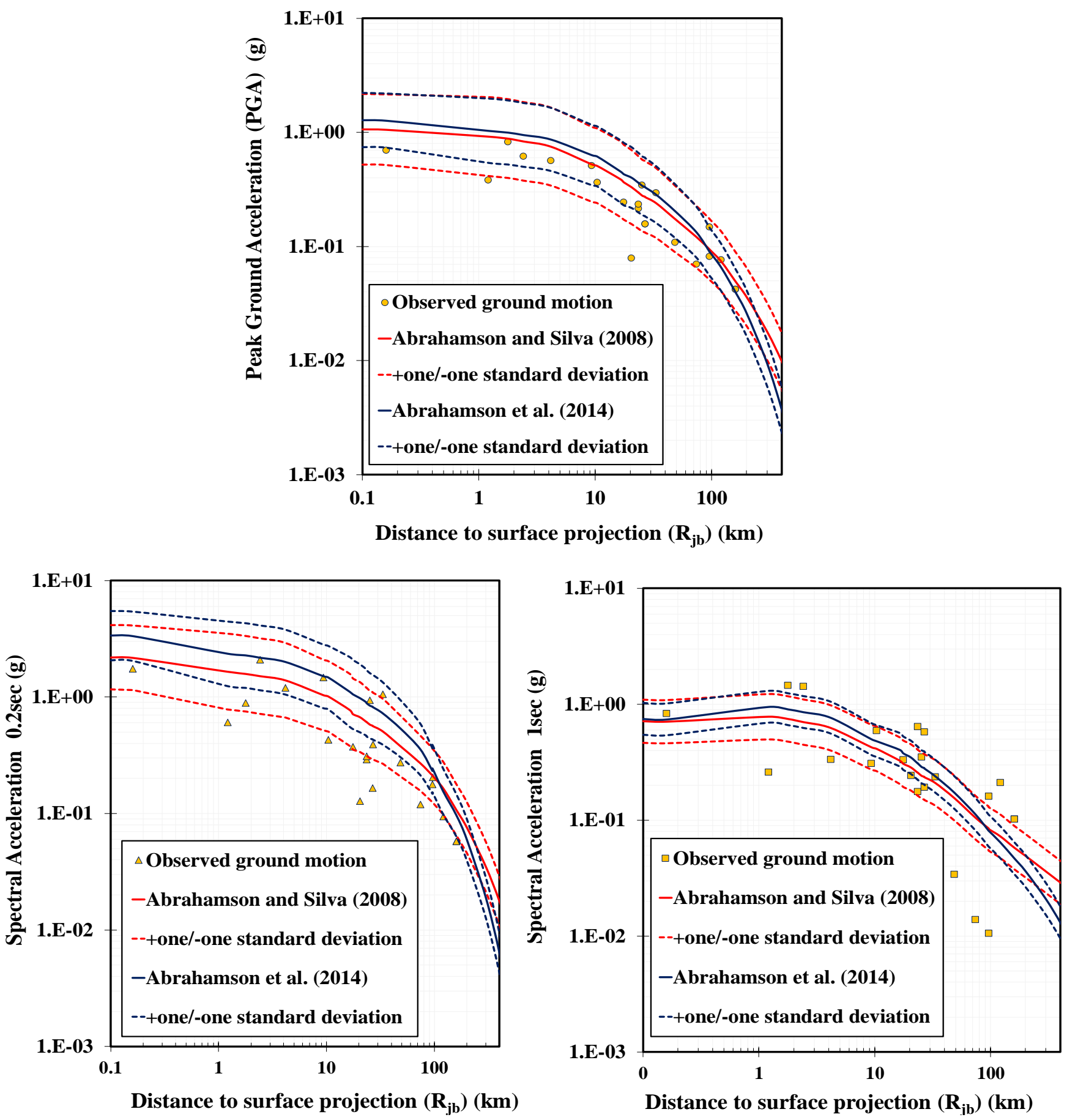

Figure 3. Comparison of NGA West 1 for Abraham-Silva (2014) and NGA West 2 for Abrahamson et al. (2014) 

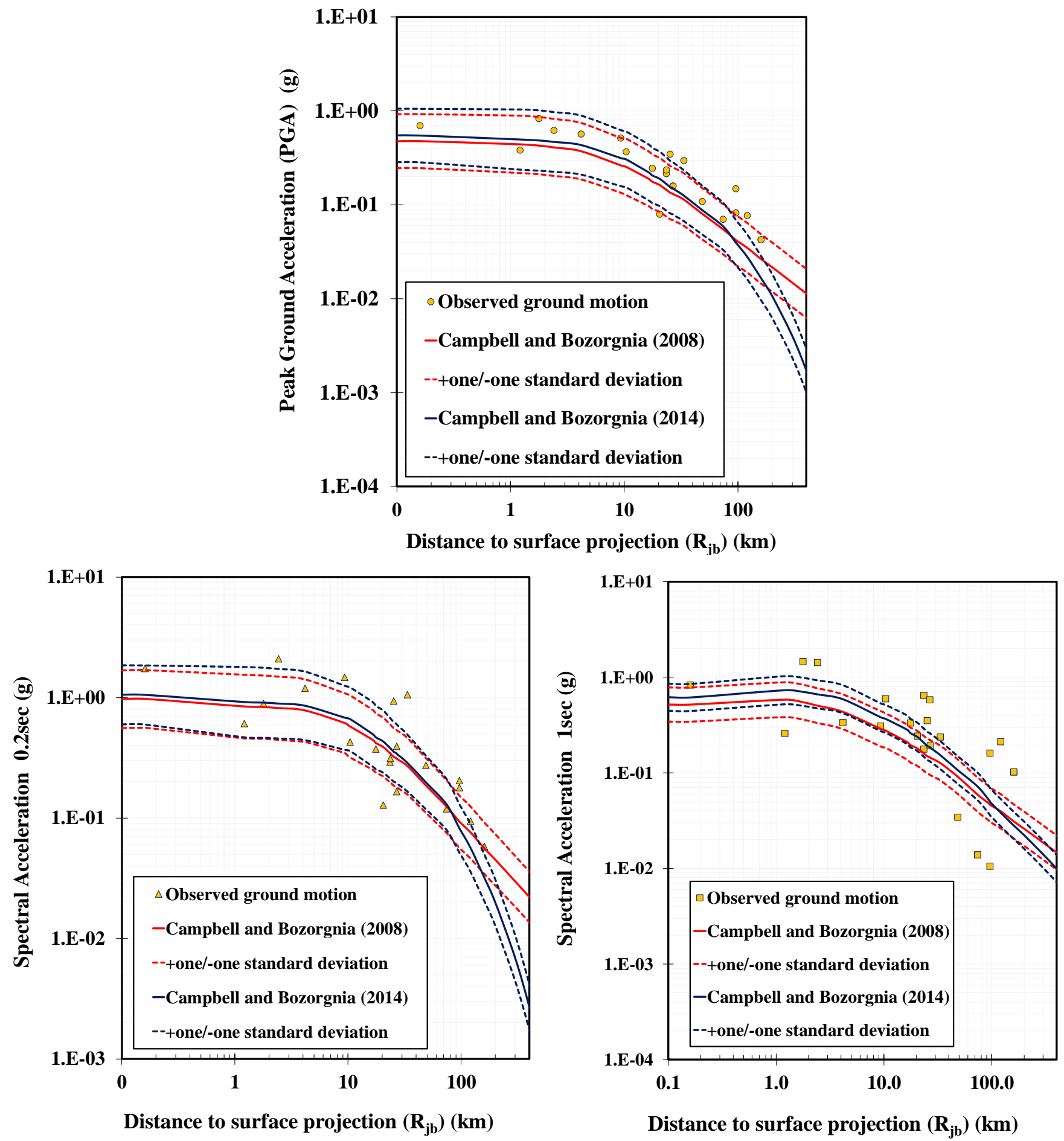

Figure 4. Comparison of NGA West 1 for Abraham-Silva (2014) and NGA West 2 for Abrahamson et al. (2014)

Table 3 summaries RMS Error NGA West 1 and NGA West 2 models estimated from Equations 3 and 4 for the Kobe Earthquake. The framework of selection the NGA models using the concept of RMS Error has been implemented by several studies, such as Mase et al. (2018a) and Likitlersuang et al. (2019). The suitable NGA models can be determined from the minimum value of RMS Error. The most suitable attenuation model would be used as the model for further analyses such as seismic ground response analysis and seismic hazard analysis (Mase et al., 2018b). From Table 3, the best model is defined as the model with the minimum RMS Error. For NGA West 1, Abrahamson and Silva's (2008) model has the minimum RMS Error of about 0.2866, whereas Boore and Atkinson's (2008) model has the minimum RMS error of $0.1242 \mathrm{sec}$ for SA at $0.2 \mathrm{sec}$ 
and 0.4054 for SA at $1 \mathrm{sec}$. For NGA West 2, the minimum RMS Error of PGA is provided from Campbell and Bozorgnia (2014). The minimum RMS Error values of SA at $0.2 \mathrm{sec}$ and SA at $1 \mathrm{sec}$ are provided by Boore et al. (2014) model and Abrahamson et al. (2014) model, respectively. Based on the results, the NGA West 2 has improved the prediction of SA for the Kobe Earthquake, especially for Spectral Acceleration. It indicates that NGA West 1 is still reliable to predict PGA of the Kobe Earthquake. The results also show that Boore and Atkinson's model

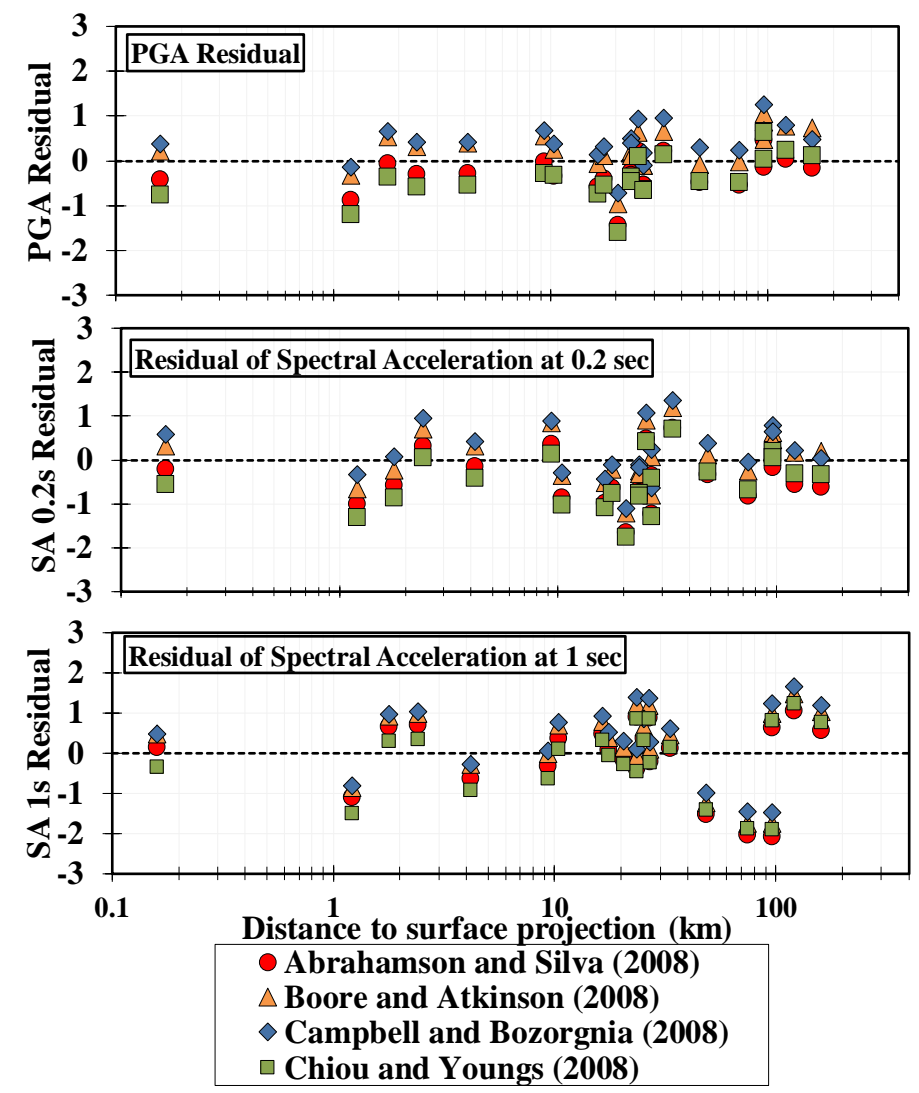

provided the best prediction of PGA and Boore et al.'s (2014) model well predicts the SA at $0.2 \mathrm{sec}$. Both Abrahamson and Silva's (2008) model and Abrahamson et al.'s (2014) relatively more accurate in predicting SA at $1 \mathrm{sec}$ of the Kobe Earthquake. For engineering practice, PGA could be useful in seismic hazard analysis, whereas SA could be useful in design of earthquake resistance building (Mase, 2018). In general, from the RMS Error values, the NGA West 1 and NGA West 2 are still reliable in predicting the ground motion of Strong Earthquake.
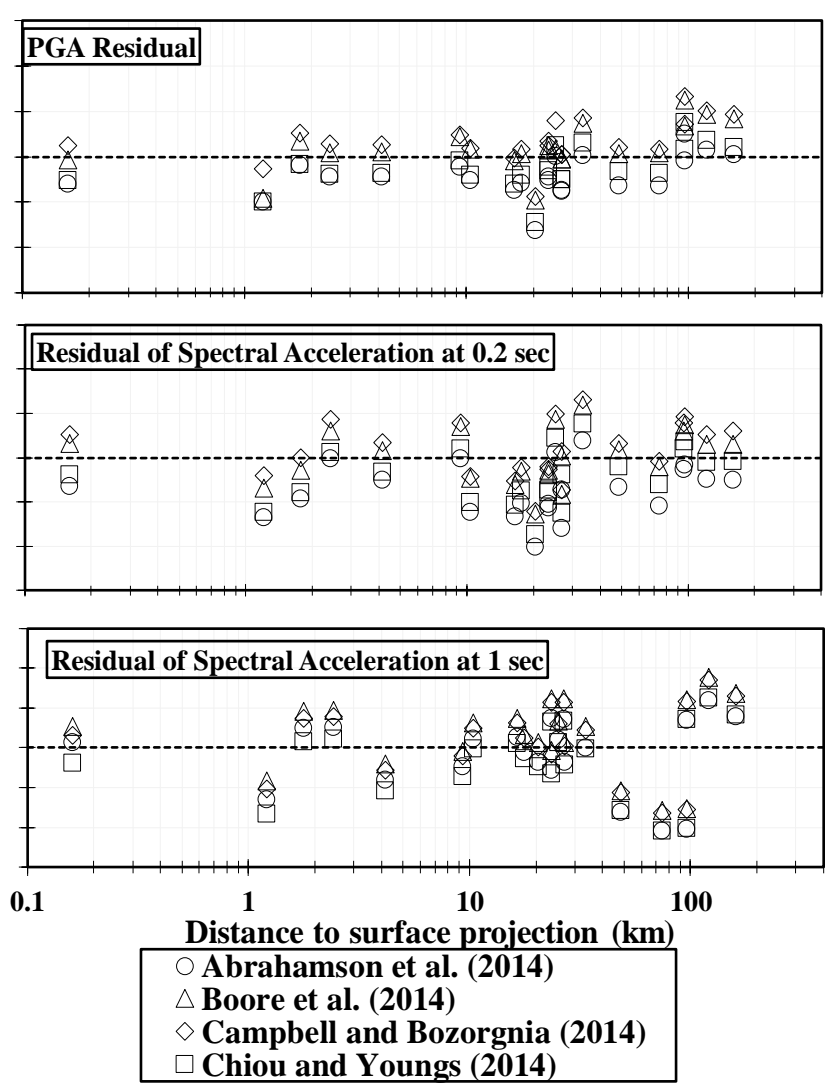

Figure 5. Residual PGA, SA at $0.2 \mathrm{sec}$, and SA at $1 \mathrm{sec}$

Table 3. RMS Error of NGA models in predicting the Kobe Earthquake

\begin{tabular}{lccc}
\hline \multirow{2}{*}{ NGA West 1 Models } & \multicolumn{3}{c}{ RMS Error } \\
\cline { 2 - 4 } & PGA & SA 0.2 sec & SA 1 sec \\
\hline Abrahamson and Silva (2008) & 0.1779 & 0.4353 & $\mathbf{0 . 2 8 6 6}$ \\
Boore and Atkinson (2008) & $\mathbf{0 . 1 2 4 2}$ & $\mathbf{0 . 4 0 5 4}$ & 0.3320 \\
Campbell and Bozorgnia (2008) & 0.1469 & 0.4459 & 0.3443 \\
Chiou and Youngs (2008) & 0.3190 & 0.6314 & 0.2969 \\
\hline \multicolumn{1}{c}{ NGA West 2 Models } & RMS Error \\
\cline { 2 - 4 } & PGA & SA 0.2 sec & SA 1 sec \\
\hline Abrahamson et al. (2014) & 0.2509 & 0.7577 & $\mathbf{0 . 2 8 6 6}$ \\
Boore et al. (2014) & 0.1491 & $\mathbf{0 . 3 8 9 4}$ & 0.3279 \\
Campbell and Bozorgnia (2014) & $\mathbf{0 . 1 4 6 9}$ & 0.4459 & 0.3443 \\
Chiou and Youngs (2014) & 0.3190 & 0.6314 & 0.2969 \\
\hline
\end{tabular}




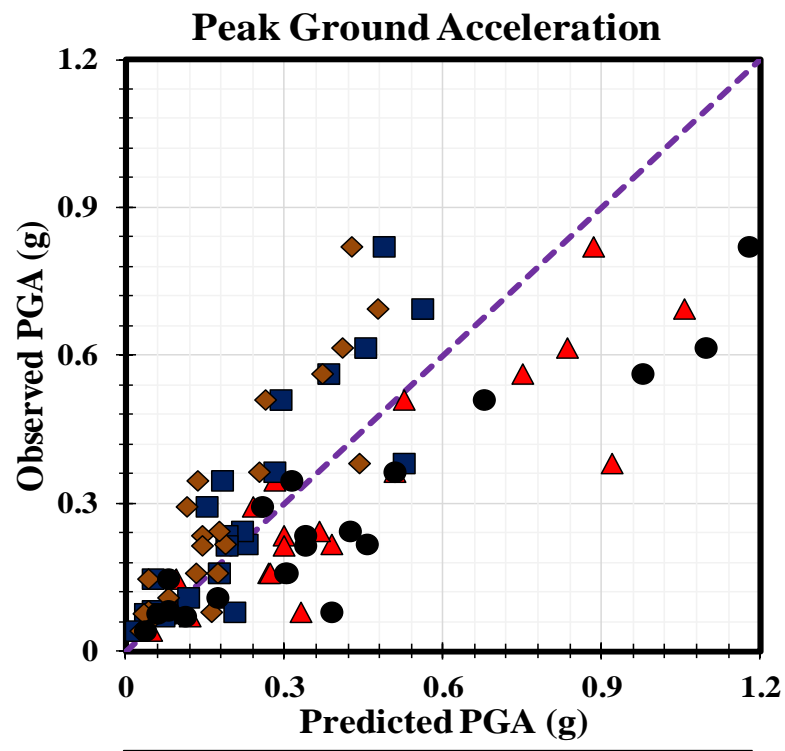

$\triangle$ Abrahamson and Silva (2008)

Boore and Atkkinson (2008)

$\diamond$ Campbell and Bozorgnia (2008)

- Chiou and Youngs (2008)
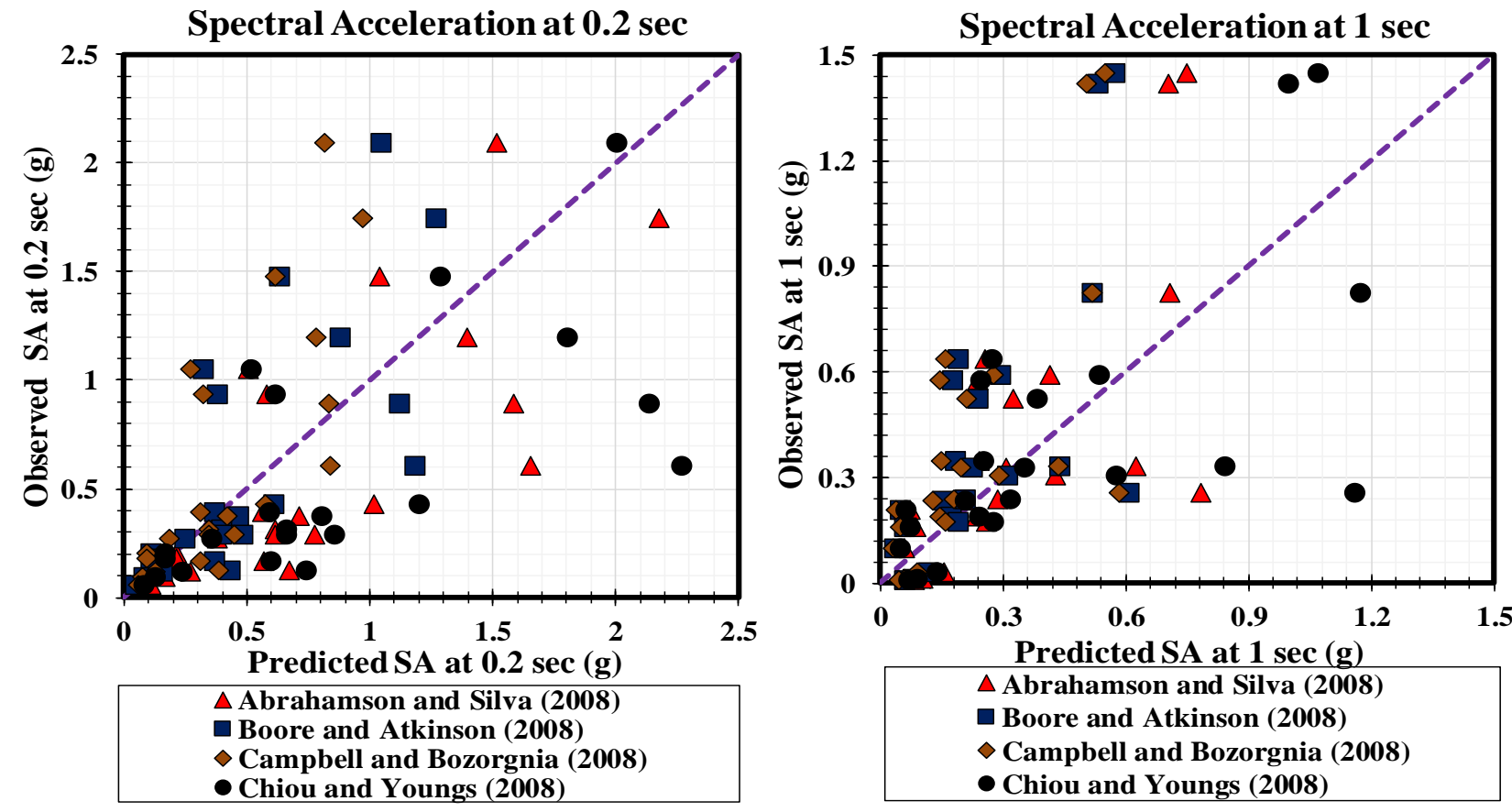

Figure 6. Relative observation of the recorded ground motion and predicted ground motion for NGA West 1 Models 

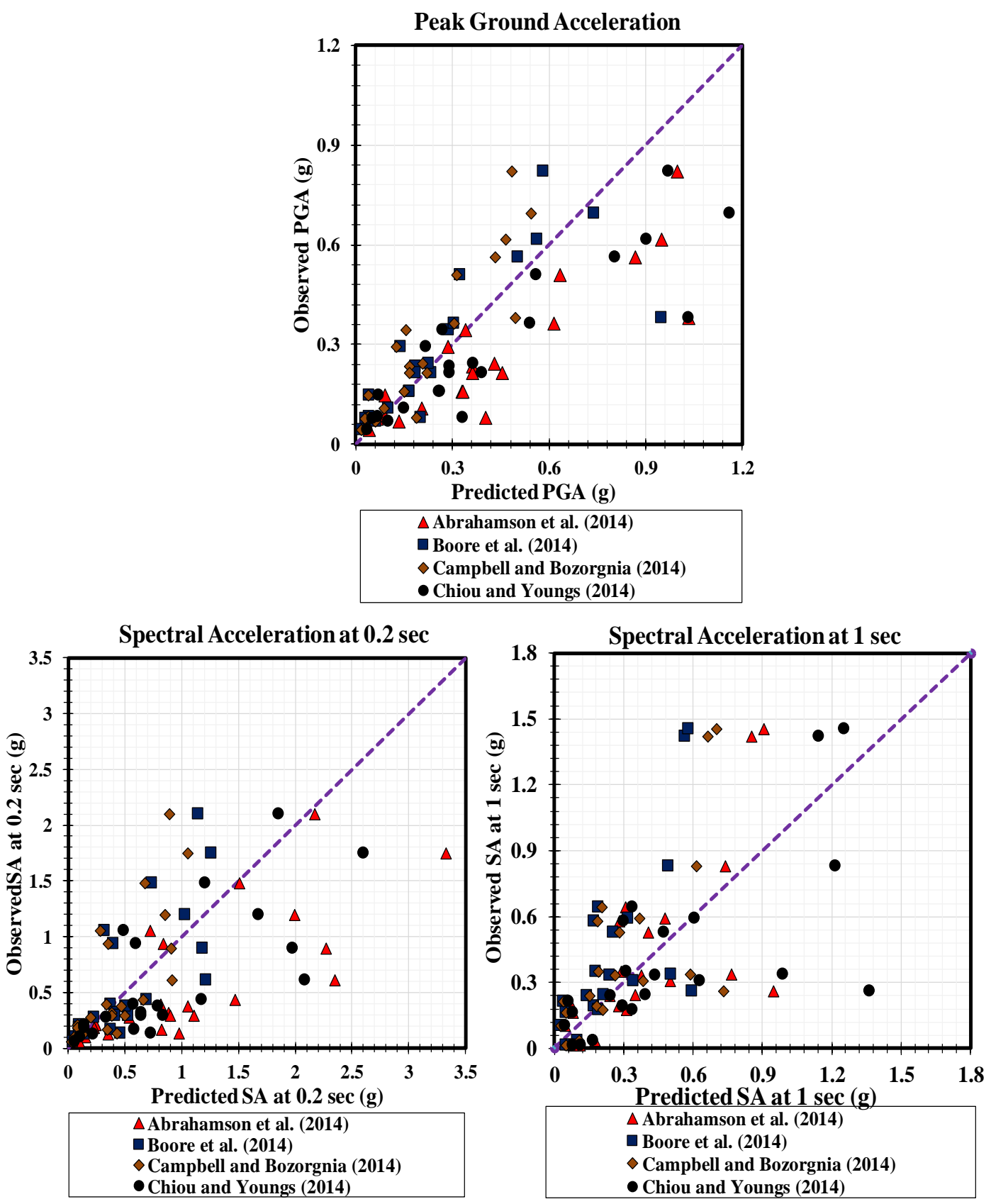

Figure 7. Relative observation of the recorded ground motion and predicted ground motion for NGA West 2 Models 


\section{CONCLUSIONS}

Performance of NGA models in predicting the ground motion of the Kobe Earthquake has been studied. The ground motion prediction based on Rjb has been performed. To observe the performance of NGA models, the residual values and RMS Error have been presented. These concluding remarks can be summarized as follows:

1. Generally, the site class of the seismic stations were dominated by Site Class $C$ and D. Therefore for the NGA Analysis the Idriss' (2008 and 2014) models were not employed.

2. NGA West 2 models as the updated version could provide a smoother prediction, which is consistent as stated by Shahi and Baker (2014). The deviation ranges of NGA West Models were relatively narrow. NGA could provide a better prediction, especially for Spectral Acceleration (SA) at $0.2 \mathrm{sec}$ and $1 \mathrm{sec}$.

3. Both NGA West 1 and NGA West 2 models presented the overestimation and underestimation. Generally, NGA West 2 models have improved the prediction, especially for PGA. The similar observation was also found by several researchers such as Mase et al. (2018a, 2018b) and Ornthammarath (2013).

4. Based on the RMS Error, Both NGA West 1 and NGA West 2 could be reliable in predicting the ground motion of strong motion, such as the Kobe Earthquake. In general, the results showed that NGA models of Abrahamson and Silva (2008), Abrahamson et al. (2014) were relatively more reliable in predicting Spectral Acceleration at 1 sec during the Kobe Earthquake, whereas model of Boore et al. (2014) and more of Boore and Atkinson (2008) were relatively more reliable in predicting Spectral Acceleration at $0.2 \mathrm{sec}$ and PGA, respectively.

5. The framework implemented in this study could be adopted in other earthquake events that are triggered by the active tectonic region around the world, which then could help in deciding the suitable NGA models.

\section{ACKNOWLEDGMENTS}

The authors would like to thank the Centre of Earthquake Strong Motion Database (CESMD) for the ground motions of the Kobe Earthquake on 17 January 1995, which were used in this study.

\section{REFERENCES}

Centre of Earthquake Strong Motion Data (CESMD) (2018) Earthquake Data of the $6.9 \mathrm{Mw}$ 1995 Great Hansin Earthquake. Available at: https://www.strongmotioncenter.org (Accessed: 26 December 2018).

Google Earth (2018) Osaka-Kobe-Kyoto Region. Available at: http://www.google.com (Accessed: 21 December 2018).

National Earthquake Hazard Reduction Program (NEHRP) (1998) Recommended Provisions for Seismic Regulation for New Buildings and other Structures 1997 edition.

Abrahamson, N. A. and Bommer, J. J. (2005) 'Probability and uncertainty in seismic hazard analysis', Earthquake Spectra, 21(2), pp. 603-607. doi: 10.1193/1.1899158.

Abrahamson, N. A., Silva, W. J. and Kamai, R. (2014) 'Summary of the ASK14 ground motion relation for active crustal regions', Earthquake Spectra, 30(1), pp. 1025-1055. doi: 10.1193/070913EQS198M.

Abrahamson, N. and Silva, W. (2008) 'Summary of the Abrahamson \& Silva NGA ground-motion relations', Earthquake Spectra, 24(1), pp. 67-97. doi: 10.1193/1.2924360.

Atkinson, G. M. (2006) 'Single-station sigma', Bulletin of the Seismological Society of America, 96(2), pp. 446-455. doi: 10.1785/0120050137.

Boore, D. M. et al. (2014) 'NGA-West2 equations for predicting PGA, PGV, and 5\% damped PSA for shallow crustal earthquakes', Earthquake Spectra, 30(3), pp. 1057-1085. doi: 10.1193/070113EQS184M.

Boore, D. M. and Atkinson, G. M. (2008) 'Groundmotion prediction equations for the average horizontal component of PGA, PGV, and 5\%- 
damped PSA at spectral periods between $0.01 \mathrm{~s}$ and 10.0 s', Earthquake Spectra, 24(1), pp. 99-138. doi: 10.1193/1.2830434.

Campbell, K. W. and Bozorgnia, Y. (2008) 'NGA ground motion model for the geometric mean horizontal component of PGA, PGV, PGD and 5\% damped linear elastic response spectra for periods ranging from 0.01 to 10 s', Earthquake Spectra, 24(1), pp. 139-171. doi: 10.1193/1.2857546.

Campbell, K. W. and Bozorgnia, Y. (2014) 'NGAWest2 ground motion model for the average horizontal components of PGA, PGV, and 5\% damped linear acceleration response spectra', Earthquake Spectra, 30(3), pp. 1085-1115. doi: 10.1193/062913EQS175M.

Chiou, B. S. J. and Youngs, R. R. (2008) 'An NGA model for the average horizontal component of peak ground motion and response spectra', Earthquake Spectra, 24(1), pp. 173-215. doi: 10.1193/1.2894832.

Chiou, B. S. J. and Youngs, R. R. (2014) 'Update of the Chiaou and Youngs NGA model for the average horizontal component of peak ground motion and response spectra', Earthquake Spectra, 30(3), pp. 1117-1153. doi: 10.1193/072813EQS219M.

Idriss, I. M. (2008) 'An NGA Empirical Model for Estimating the Horizontal Spectral Values Generated By Shallow Crustal Earthquakes', Earthquake Spectra, 24(1), pp. 217-242. doi: 10.1193/1.2924362.

Idrissa, I. M. (2014) 'An NGA-West2 empirical model for estimating the horizontal spectral values generated by shallow crustal earthquakes', Earthquake Spectra, 30(3), pp. 1155-1177. doi: 10.1193/070613EQS195M.

Katayama, T. (2004) 'Earthquake disaster risk mitigation before and after the 1995 Kobe earthquake', in 13th World Conference on Earthquake Engineering.

Kramer, S. L. (1996) Geotechnical earthquake engineering. Prentice Hall.
Kusumahadi, Y., Soralump, S.\& Prempramote, S. (2018) 'Estimation of Liquefaction-Induced Building Settlement Due to 6.3 Mw Chiang Rai Earthquake 2014', in Proceeeding of the 8th Regional Symposium on Infrastructure Development in Civil Engineering (RSID8).

Likitlersuang, S. et al. (2019) 'Influence of spatial variability of ground on seismic response analysis: a case study of Bangkok subsoils', Bulletin of Engineering Geology and the Environment, pp. 1-13. doi: 10.1007/s10064-01901560-9.

Mase, L. Z. et al. (2018) 'Local Site Investigation of Liquefied Soils Caused by Earthquake in Northern Thailand', Journal of Earthquake Engineering, 22(6), pp. 1-25. doi: 10.1080/13632469.2018.1469441.

Mase, L. Z. (2018) 'Reliability study of spectral acceleration designs against earthquakes in Bengkulu City, Indonesia', International Journal of Technology, 9(5), pp. 910-924. doi: 10.14716/ijtech.v9i5.621.

Mase, L. Z., Likitlersuang, S. and Tobita, T. (2018a) 'Analysis of seismic ground response caused during strong earthquake in Northern Thailand', Soil Dynamics and Earthquake Engineering, 114(11), pp. 113-126. doi: 10.1016/j.soildyn.2018.07.006.

Mase, L. Z., Likitlersuang, S. and Tobita, T. (2018b) 'Non-linear site response analysis of soil sites in northern Thailand during the Mw 6.8 tarlay Earthquake', Engineering Journal, 22(3), pp. 291-303. doi: 10.4186/ej.2018.22.3.291.

Ornthammarath, T. (2013) 'A note on the strong ground motion recorded during the $\mathrm{Mw} 6.8$ earthquake in Myanmar on 24 March 2011', Bulletin of Earthquake Engineering, 11(1), pp. 241254. doi: 10.1007/s10518-012-9385-4.

Ornthammarath, T. and Warnitchai, P. (2016) '5 May 2014 MW 6.1 Mae Lao (Northern Thailand) earthquake: Interpretations of recorded ground motion and structural damage', Earthquake Spectra, 32(3), pp. 1209-1238. doi: 10.1193/081814EQS129M. 
Rhoades, D.A. \& Dowrick, D. J. (2000) 'Effects of Magnitude Uncertainties on Seismic Hazard Estimates', in Proceeding of the 12th World Conference on Earthquake Engineering. Auckland.

Shahi, S. K. and Baker, J. W. (2014) 'NGA-West2 models for ground motion directionality', Earthquake Spectra, 30(3), pp. 1285-1300. doi: 10.1193/040913EQS097M.

Shoja-Taheri, J., Naserieh, S. and Hadi, G. (2010) 'A test of the applicability of NGA models to the strong ground-motion data in the Iranian plateau', Journal of Earthquake Engineering, 14(2), pp. 278-292. doi: 10.1080/13632460903086051.
Soga, K. (1998) 'Soil liquefaction effects observed in the kobe earthquake of 1995', Proceedings of the Institution of Civil Engineers: Geotechnical Engineering, 131(1), pp. 34-51. doi: 10.1680/igeng.1998.30004.

Tamura, K. (2014) 'Seismic design of highway bridge foundations with the effects of liquefaction since the 1995 Kobe earthquake', Soils and Foundations, 54(4), pp. 874-882. doi: 10.1016/j.sandf.2014.06.017.

Wakamatsu, K. and Numata, A. (2014) 'The Effect of Liquefaction Susceptibility on Building Damage During the 1995 Kobe Earthquake', in Proceeding of the 13th World Conference on Earthquake Engineering. Vancouver. 